\title{
Non-emphysematous chronic obstructive pulmonary disease is associated with diabetes mellitus
}

Craig P Hersh ${ }^{1,2^{*}}$, Barry J Make ${ }^{3}$, David A Lynch ${ }^{4}$, R Graham Barr ${ }^{5}$, Russell P Bowler ${ }^{3}$, Peter MA Calverley ${ }^{6}$, Peter J Castaldi ${ }^{1}$, Michael H Cho ${ }^{1,2}$, Harvey O Coxson ${ }^{7}$, Dawn L DeMeo ${ }^{1,2}$, Marilyn G Foreman ${ }^{8}$, MeiLan K Han ${ }^{9}$, Benjamin J Harshfield ${ }^{1}$, John E Hokanson ${ }^{10}$, Sharon Lutz ${ }^{11}$, Joe W Ramsdell ${ }^{12}$, Elizabeth A Regan ${ }^{3}$, Stephen I Rennard ${ }^{13}$, Joyce D Schroeder ${ }^{4}$, Frank C Sciurba ${ }^{14}$, Robert M Steiner ${ }^{15}$, Ruth Tal-Singer $^{16}$, Edwin JR van Beek ${ }^{17}$, Edwin K Silverman ${ }^{1,2}$, James D Crapo ${ }^{3}$ and the COPDGene and ECLIPSE Investigators

\begin{abstract}
Background: Chronic obstructive pulmonary disease (COPD) has been classically divided into blue bloaters and pink puffers. The utility of these clinical subtypes is unclear. However, the broader distinction between airway-predominant and emphysema-predominant COPD may be clinically relevant. The objective was to define clinical features of emphysema-predominant and non-emphysematous COPD patients.
\end{abstract}

Methods: Current and former smokers from the Genetic Epidemiology of COPD Study (COPDGene) had chest computed tomography (CT) scans with quantitative image analysis. Emphysema-predominant COPD was defined by low attenuation area at -950 Hounsfield Units $\left(\right.$ LAA_950 $_{2} \geq 10 \%$. Non-emphysematous COPD was defined by airflow obstruction with minimal to no emphysema (LAA-950 $<5 \%)$.

Results: Out of 4197 COPD subjects, 1687 were classified as emphysema-predominant and 1817 as non-emphysematous; 693 had LAA_950 between 5-10\% and were not categorized. Subjects with emphysema-predominant COPD were older (65.6 vs 60.6 years, $p<0.0001$ ) with more severe COPD based on airflow obstruction ( $\mathrm{FEV}_{1} 44.5$ vs 68.4\%, p<0.0001), greater exercise limitation (6-minute walk distance 1138 vs $1331 \mathrm{ft}, \mathrm{p}<0.0001$ ) and reduced quality of life (St. George's Respiratory Questionnaire score 43 vs 31, p < 0.0001 ). Self-reported diabetes was more frequent in non-emphysematous COPD (OR 2.13, p $<0.001$ ), which was also confirmed using a strict definition of diabetes based on medication use. The association between diabetes and non-emphysematous COPD was replicated in the ECLIPSE study.

Conclusions: Non-emphysematous COPD, defined by airflow obstruction with a paucity of emphysema on chest CT scan, is associated with an increased risk of diabetes. COPD patients without emphysema may warrant closer monitoring for diabetes, hypertension, and hyperlipidemia and vice versa.

Trial registration: Clinicaltrials.gov identifiers: COPDGene NCT00608764, ECLIPSE NCT00292552.

Keywords: Airway disease, CT scan, Diabetes mellitus, Emphysema, Spirometry

\footnotetext{
* Correspondence: craig.hersh@channing.harvard.edu

${ }^{1}$ Channing Division of Network Medicine, Boston, MA, USA

'Division of Pulmonary and Critical Care Medicine, Brigham and Women's

Hospital, Boston, MA, USA

Full list of author information is available at the end of the article
} 


\section{Background}

Chronic obstructive pulmonary disease (COPD) is a heterogeneous disease, including emphysema and large and small airway disease. The most recent update from the Global Initiative for Obstructive Lung Disease (GOLD) has addressed COPD subgroups [1], and there is a recognized need to better define COPD subtypes [2]. Several COPD subtypes have been shown to respond to specific treatments, including long-term oxygen for hypoxemic patients $[3,4]$, lung volume reduction surgery for upper lobe predominant emphysema [5], and medications including inhaled corticosteroids, azithromycin and roflumilast for frequent acute exacerbations [6-8].

Classic COPD subtypes include the "pink puffer" (underweight, emphysema, and normal resting oxygen saturation) and the "blue bloater" (overweight, chronic bronchitis, and hypoxemia) [9]. Though not appearing in the GOLD document and other management guidelines $[1,10]$, these subtypes persist in textbooks $[11,12]$. The pink puffer - blue bloater distinction is vaguely defined and only applies to severe COPD patients, potentially limiting its clinical utility. However, the distinction between airway-predominant and emphysemapredominant COPD, which has some parallels to the pink puffer - blue bloater classification, may still have utility [13-17]. Historically, determinations about the extent of emphysema and airway disease could only be made on pathological specimens; however, chest computed tomography (CT) scans provide extensive anatomic information about COPD [18,19]. As chest CT scans are becoming more frequently used for lung cancer screening and other indications [20,21], these subtypes may be more easily identified in COPD patients.

The Genetic Epidemiology of COPD Study (COPDGene) has enrolled over 10,000 smokers with and without COPD across the United States [22]. The large sample size with extensive clinical data, including volumetric chest CT scans, allows for COPD subtyping. We aimed to create a simplified distinction between emphysema-predominant and presumed airway-predominant COPD based on the presence or absence of emphysema on chest CT scan. We hypothesized that these COPD subtypes would show associations with clinical characteristics and co-morbidities that have implications for the evaluation and management of patients with COPD. We assessed generalizability by replicating subtype associations in the Evaluation of COPD Longitudinally to Identify Predictive Surrogate End-points (ECLIPSE) Study [23].

\section{Methods}

\section{Study subjects}

COPDGene enrolled smokers with and without COPD at 21 clinical centers throughout the United States between 2007-2011 [22]. Subjects were self-classified
non-Hispanic whites and non-Hispanic African Americans ages 45-80 with at least 10 pack-years of lifetime smoking. During the study visit, subjects underwent a limited physical examination, spirometry before and after inhaled bronchodilator, and a six-minute walk test to assess exercise capacity. Subjects completed questionnaires on respiratory disease, medical history and medications. The St. George's Respiratory Questionnaire (SGRQ) measured disease-related quality of life [24]. Study protocols and questionnaires are available at www.copdgene.org. The ECLIPSE study is described in the Supplementary Methods (Additional file 1) [23]. COPDGene and ECLIPSE were approved by the institutional review boards at Partners Healthcare and all participating centers (Additional files 2 and 3). Subjects provided written informed consent.

\section{Chest CT scans}

All subjects underwent a volumetric chest CT scan performed at full inspiration and at relaxed expiration. All chest CT scans were subjected to a standard quality control procedure. Quantitative image analysis was performed using 3D SLICER $[25,26]$ and VIDA Pulmonary Workstation software (Vida Diagnostics, Coralville, Iowa). Emphysema was quantified by the percent of lung voxels with attenuation $\leq-950$ Hounsfield Units (HU) on inspiratory scan [27]. Subjects were considered to have emphysema-predominant COPD if this value exceeded $10 \%$, corresponding to 3 standard deviations above the mean in normal non-smokers from COPDGene [28]. In contrast, non-emphysematous COPD was defined by minimal to absent emphysema, specifically $<5 \%$ (mean $+1 \mathrm{SD}$ in normal non-smokers). Airway disease was assessed by the wall area percent of segmental airways and as the square root wall area of a hypothetical airway with $10 \mathrm{~mm}$ internal perimeter (SRWA-Pi10) [19].

\section{Statistical analysis}

We used the COPDGene dataset version date 19September-2012. The analysis was restricted to subjects with airflow obstruction, defined by $\mathrm{FEV}_{1} / \mathrm{FVC}<0.7$ after bronchodilator, corresponding to GOLD stages 1-4 [1]. Based on expert opinion and previous COPDGene publications, we selected a set of clinical phenotypes and comorbidities to compare across the imaging subtypes (Table 1) [29-37]. Univariate comparisons used t-tests for continuous variables and chi-squared tests for binary variables. Logistic regression models were used to adjust for covariates including age, sex, race, body mass index, current smoking status, lifetime pack-years of smoking, and severity of airflow obstruction, assessed as post-bronchodilator $\mathrm{FEV}_{1}$ percent predicted. Stratified logistic regression models were adjusted for the same covariates excluding the quantitative of categorical variable that was used to define the strata (e.g. models in 
Table 1 COPD characteristics and comorbidity definitions

\begin{tabular}{|c|c|c|}
\hline Characteristic or comorbidity & Definition & $\begin{array}{l}\text { COPDGene reference, } \\
\text { if applicable }\end{array}$ \\
\hline Asthma-COPD overlap & Self-report of physician diagnosis of asthma before age 40 & Hardin 2011 [29] \\
\hline Hypoxemia & Resting oxygen saturation $\leq 88 \%$ & Kim 2011 [30] \\
\hline Frequent exacerbator & $\begin{array}{l}2 \text { or more exacerbations requiring antibiotics and/or systemic steroids in } \\
\text { the year prior to enrollment }\end{array}$ & Han 2011 [33] \\
\hline Severe, early-onset COPD & Age $<55$ years, $\mathrm{FEV}_{1}<50 \%$ predicted & Foreman 2011 [34] \\
\hline Poor exercise capacity & 6-minute walk distance $<500$ feet & Rambod 2012 [32] \\
\hline Bronchodilator response & Increase in $\mathrm{FEV}_{1} 200 \mathrm{ml}$ and 12\% from baseline & \\
\hline Pink puffer & Emphysema $>10 \%, \mathrm{BMI} \leq 20, \mathrm{O}_{2}$ sat $\geq 90 \%$ & \\
\hline Blue bloater & Chronic bronchitis, $\mathrm{BMI}>25, \mathrm{O}_{2}$ sat $<90 \%$ & \\
\hline Chronic bronchitis & Chronic cough and phlegm for $\geq 3 \mathrm{mo} / \mathrm{yr}$ for at least 2 consecutive years & Kim 2011 [31] \\
\hline Chronic prednisone use & Self-report & Swift 2012 [35] \\
\hline Cardiovascular disease & $\begin{array}{l}\text { Self-report of heart attack, coronary artery disease, angina, angioplasty, } \\
\text { coronary artery bypass graft, congestive heart failure, peripheral vascular } \\
\text { disease, transient ischemic attack or stroke }\end{array}$ & Black-Shinn 2014 [36] \\
\hline Coronary disease & $\begin{array}{l}\text { Self-report of heart attack, coronary artery disease, angina, angioplasty, } \\
\text { or coronary artery bypass graft }\end{array}$ & \\
\hline Congestive heart failure & Self-report & \\
\hline Peripheral vascular disease & Self-report & \\
\hline Cerebrovascular disease & Self-report of transient ischemic attack or stroke & \\
\hline Sleep apnea & Self-report & \\
\hline Diabetes mellitus & Self-report & Kinney 2014 [37] \\
\hline Metabolic syndrome & $\begin{array}{l}3 \text { of } 4 \text { : BMI > } 30 \text { (measured), diabetes mellitus, hypertension, and high } \\
\text { cholesterol (all self-report) }\end{array}$ & \\
\hline Gastroesophageal reflux disease & Self-report & \\
\hline Peptic ulcer disease & Self-report & \\
\hline Osteoporosis & Self-report & \\
\hline
\end{tabular}

obese and non-obese subjects were not adjusted for BMI). Analyses were performed using $\mathrm{R}$ statistical software. Logistic regression analysis for diabetes in ECLIPSE is described in the Additional file 1.

\section{Results}

COPDGene enrolled 10,300 subjects. There were 4197 current and former smokers with airflow obstruction $\left(\mathrm{FEV}_{1} / \mathrm{FVC}<0.7\right.$ on post-bronchodilator spirometry) and inspiratory chest CT scans passing quality control included in this analysis. Figure 1 demonstrates that the classic COPD subtypes of pink puffers and blue bloaters increased in frequency in more severe COPD, yet these subjects remained infrequent even among subjects with the most severe airflow obstruction (see Table 1 for definitions). Blue bloaters were less common than pink puffers across all level of lung function impairment.

Of the 4197 COPD subjects, 1687 subjects were defined as emphysema-predominant and 1817 as nonemphysematous (Table 2, Figure 2). 693 subjects had

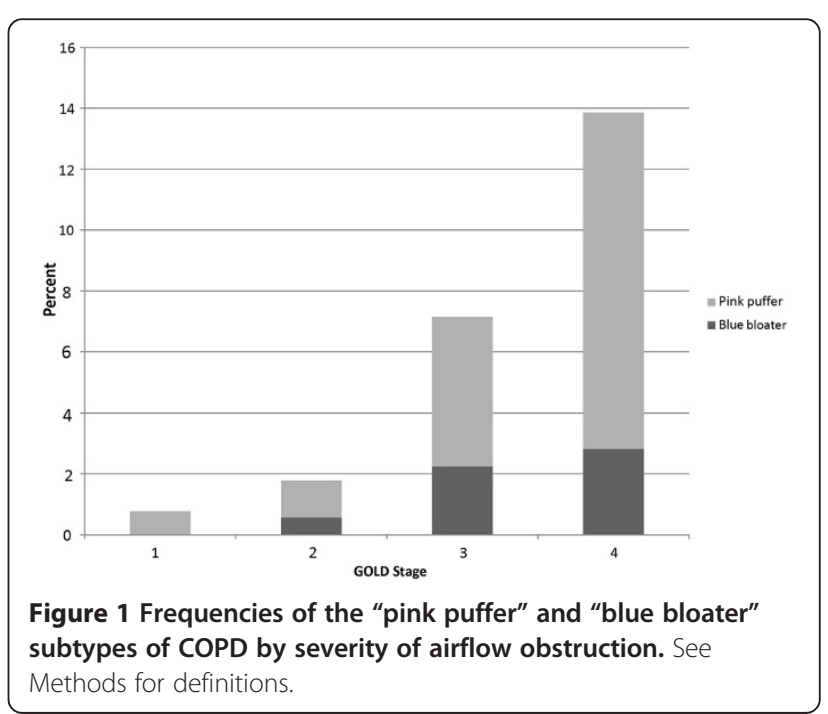


Table 2 Demographic and clinical attributes of subjects with non-emphysematous and emphysema-predominant COPD (GOLD 1-4)

\begin{tabular}{|c|c|c|c|}
\hline & No/minimal emphysema & Emphysema-predominant & p-value \\
\hline N & 1817 & 1687 & \\
\hline Age & $60.6( \pm 8.8)$ & $65.6( \pm 7.7)$ & $<0.0001$ \\
\hline Male sex & $933(51.3 \%)$ & $1000(59.3 \%)$ & $<0.0001$ \\
\hline African American race & $479(26.4 \%)$ & $288(17.1 \%)$ & $<0.0001$ \\
\hline Pack-years of smoking & $47.3( \pm 24.4)$ & $55.9( \pm 28.1)$ & $<0.0001$ \\
\hline Current smoking & $1122(61.8 \%)$ & $392(23.2 \%)$ & $<0.0001$ \\
\hline Body Mass Index, kg/m² & $29.3( \pm 6.3)$ & $25.9( \pm 5.2)$ & $<0.0001$ \\
\hline Forced Expiratory Volume in $1 \mathrm{~s}\left(\mathrm{FEV}_{1}\right), \%$ predicted & $68.4( \pm 18.4)$ & $44.5( \pm 21.0)$ & $<0.0001$ \\
\hline \multicolumn{4}{|l|}{ GOLD Stage } \\
\hline 1 & $487(26.8 \%)$ & $121(7.2 \%)$ & \\
\hline 2 & $1025(56.4 \%)$ & $453(26.9 \%)$ & \\
\hline 3 & $267(14.7 \%)$ & $649(38.5 \%)$ & \\
\hline 4 & $38(2.1 \%)$ & $464(27.5 \%)$ & \\
\hline $\mathrm{FEV}_{1}$ / Forced Vital Capacity ratio & $0.61( \pm 0.08)$ & $0.42( \pm 0.12)$ & $<0.0001$ \\
\hline Bronchodilator response, change in $\mathrm{FEV}_{1}, \%$ of baseline & $7.2( \pm 11.7)$ & $9.1( \pm 12.6)$ & $<0.0001$ \\
\hline Bronchodilator response, change in $\mathrm{FEV}_{1}, \mathrm{~L}$ & $0.11( \pm 0.19)$ & $0.09( \pm 0.13)$ & 0.001 \\
\hline Bronchodilator response, \% of predicted $\mathrm{FEV}_{1}$ & $3.8( \pm 6.4)$ & $3.2( \pm 4.5)$ & 0.002 \\
\hline 6-minute walk distance, $\mathrm{ft}$. & $1331( \pm 383)$ & $1138( \pm 403)$ & $<0.0001$ \\
\hline Oxygen saturation by pulse oximetry, $\%$ & $95.9( \pm 2.8)$ & $94.0( \pm 3.9)$ & $<0.0001$ \\
\hline Modified Medical Research Council dyspnea score & $1.5( \pm 1.5)$ & $2.4( \pm 1.3)$ & $<0.0001$ \\
\hline St. George's Respiratory Questionnaire total score & $30.7( \pm 22.9)$ & $43.0( \pm 20.6)$ & $<0.0001$ \\
\hline BODE index* & $1.6( \pm 1.7)$ & $3.6( \pm 2.1)$ & $<0.0001$ \\
\hline Emphysema at -950 Hounsfield units, \% & $2.0( \pm 1.4)$ & $23.6( \pm 10.7)$ & $<0.0001$ \\
\hline Square root wall area of an airway with $10 \mathrm{~mm}$ internal perimeter & $3.71( \pm 0.15)$ & $3.70( \pm 0.13)$ & 0.001 \\
\hline Wall area \% of segmental airways & $62.7( \pm 3.4)$ & $62.2( \pm 3.0)$ & $<0.0001$ \\
\hline
\end{tabular}

*BODE = Body mass, airflow Obstruction, Dyspnea, Exercise capacity [38] Mean $( \pm \mathrm{SD})$ or $\mathrm{N}(\%)$ are shown.

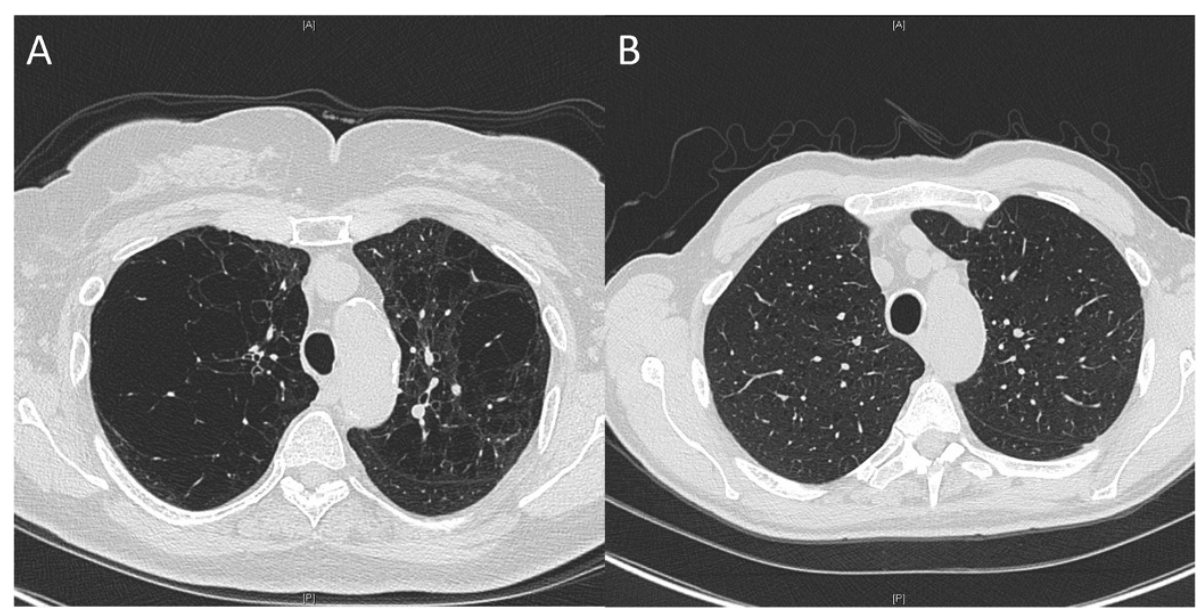

Figure 2 Chest CT scans from COPDGene subjects demonstrating emphysema-predominant and non-emphysematous COPD.

(A) Emphysema-predominant: FEV $155.8 \%$ predicted, 29.0\% emphysema. (B) Non-emphysematous: FEV 1 55.3\% predicted, 4.2\% emphysema. 
emphysema values between $5-10 \%$ and could not be classified into one of the two categories (Additional file 4: Table S1). Emphysema-predominant subjects had more severe COPD, based on lower lung function, reduced exercise capacity on 6-minute walk test, more severe dyspnea, and reduced quality of life (higher scores on SGRQ). Non-emphysematous subjects had greater bronchodilator responsiveness expressed as the absolute change in $\mathrm{FEV}_{1}$ and as the change in $\mathrm{FEV}_{1}$ as a percent of predicted $\mathrm{FEV}_{1}$, while emphysema-predominant subjects had greater change expressed as a percent of baseline $\mathrm{FEV}_{1}$. Non-emphysematous subjects had thicker airways. The characteristics of the unclassified subjects with $5-10 \%$ emphysema generally fell between the nonemphysematous and emphysema predominant subjects (Additional file 4: Table S1).

Table 3 shows the associations of the clinical characteristics and co-morbidities with the imaging subtypes. The COPD-asthma overlap group is more common in non-emphysematous COPD, as is bronchodilator responsiveness, when assessed using the American Thoracic Society/European Respiratory Society criteria [39]. Underweight subjects are more common among emphysema-predominant COPD. There was no difference in the prevalence of chronic bronchitis between the two imaging subtypes. Cardiovascular disease by various definitions, though statistically different between the imaging subtypes in the multivariate regression models, was not seen more frequently in non-emphysematous subjects, with the possible exception of congestive heart failure (Table 3). Both diabetes mellitus and the metabolic syndrome are significantly more common in nonemphysematous COPD (diabetes OR 2.13, p $<0.0001$; metabolic syndrome OR 1.87, $\mathrm{p}<0.0001)$. Using a stricter diabetes definition of self-report plus medication use (see methods in Additional file 1), there was a significant association with non-emphysematous COPD (OR 2.45, $\mathrm{p}<0.0001)$. The associations with self-reported diabetes and the metabolic syndrome were similar in analyses restricted to subjects with $\mathrm{FEV}_{1}<80 \%$ predicted (data not shown).

To ensure that the associations with diabetes and the metabolic syndrome were not due to confounding, we performed logistic regression analyses stratified by various potential confounding factors (Table 4 and Additional file 4: Table S2). The increased frequency of diabetes in

Table 3 Associations of non-emphysematous and emphysema-predominant COPD with other clinical subgroups and comorbidities

\begin{tabular}{|c|c|c|c|c|}
\hline & & uency & Logistic re & sion \\
\hline & Non-emphysematous & Emphysema-predominant & OR (adjusted)* & p-value \\
\hline COPD/asthma overlap & $281(15.5 \%)$ & $178(10.6 \%)$ & 1.64 & 0.0006 \\
\hline Hypoxemia & $44(2.4 \%)$ & $159(9.4 \%)$ & 0.76 & 0.2 \\
\hline Frequent exacerbator & $208(11.4 \%)$ & $330(19.6 \%)$ & 0.88 & 0.3 \\
\hline Severe, early-onset COPD & $91(5.0 \%)$ & $111(6.6 \%)$ & 1.07 & 0.9 \\
\hline Poor exercise capacity & $51(2.8 \%)$ & $119(7.1 \%)$ & 0.93 & 0.8 \\
\hline Bronchodilator response, ATS/ERS definition [39] & $634(34.9 \%)$ & $569(33.7 \%)$ & 1.20 & 0.05 \\
\hline Chronic prednisone use & $44(2.4 \%)$ & $124(7.4 \%)$ & 0.73 & 0.2 \\
\hline Low body mass index & $59(3.2 \%)$ & $180(10.7 \%)$ & 0.39 & $<0.0001$ \\
\hline Chronic bronchitis & $470(25.9 \%)$ & $431(25.5 \%)$ & 0.87 & 0.2 \\
\hline Cardiovascular disease & $393(21.6 \%)$ & $399(23.7 \%)$ & 1.44 & 0.0009 \\
\hline Coronary disease & $277(15.2 \%)$ & $278(16.5 \%)$ & 1.36 & 0.01 \\
\hline Congestive heart failure & $91(5.0 \%)$ & $59(3.5 \%)$ & 3.76 & $<0.0001$ \\
\hline Peripheral vascular disease & $58(3.2 \%)$ & $53(3.1 \%)$ & 1.59 & 0.07 \\
\hline Cerebrovascular disease & $96(5.3 \%)$ & $102(6.0 \%)$ & 1.14 & 0.5 \\
\hline Sleep apnea & $271(14.9 \%)$ & 199 (11.8\%) & 1.17 & 0.3 \\
\hline Diabetes mellitus & $263(14.5 \%)$ & $146(8.7 \%)$ & 2.13 & $<0.0001$ \\
\hline Metabolic syndrome & $360(19.8 \%)$ & $173(10.3 \%)$ & 1.87 & $<0.0001$ \\
\hline Gastroesophageal reflux disease & $498(27.4 \%)$ & $511(30.3 \%)$ & 0.93 & 0.5 \\
\hline Stomach ulcers & $147(8.1 \%)$ & $183(10.8 \%)$ & 0.76 & 0.07 \\
\hline Osteoporosis & $278(15.3 \%)$ & $372(22.1 \%)$ & 0.96 & 0.7 \\
\hline
\end{tabular}

*All models were adjusted for age, sex, race, pack-years, current smoking status, BMI, and FEV $\%$ predicted, except low body mass index regression which was adjusted for the same covariates excluding BMI. Odds ratio is for non-emphysematous compared to emphysema-predominant COPD. 
Table 4 Stratified logistic regression analyses for diabetes

\begin{tabular}{|c|c|c|c|c|c|}
\hline Variable & Stratum & Non-emphysematous & Emphysema-predominant & OR (adjusted)* & p-value \\
\hline \multirow[t]{2}{*}{ Obesity } & $\mathrm{BMI} \leq 30$ & $89(8.2 \%)$ & $90(6.6 \%)$ & 1.82 & 0.004 \\
\hline & $\mathrm{BMI}>30$ & $174(23.8 \%)$ & $56(17.0 \%)$ & 2.71 & $<0.001$ \\
\hline \multirow[t]{2}{*}{ Current smoker } & No & $126(18.1 \%)$ & $123(9.5 \%)$ & 1.87 & $<0.001$ \\
\hline & Yes & $137(12.2 \%)$ & $23(5.9 \%)$ & 2.85 & $<0.001$ \\
\hline \multirow[t]{2}{*}{ GOLD Stage } & $1-2$ & $191(12.6 \%)$ & $47(8.2 \%)$ & 1.87 & 0.001 \\
\hline & $3-4$ & $72(23.6 \%)$ & $99(8.9 \%)$ & 2.11 & 0.001 \\
\hline \multirow[t]{2}{*}{ Race } & Non-Hispanic white & $185(13.8 \%)$ & $113(8.1 \%)$ & 2.23 & $<0.001$ \\
\hline & African American & $78(16.3 \%)$ & $33(11.5 \%)$ & 1.96 & 0.02 \\
\hline \multirow[t]{2}{*}{ Age } & $<65$ & $147(11.8 \%)$ & $53(7.1 \%)$ & 2.07 & 0.001 \\
\hline & $\geq 65$ & $116(20.2 \%)$ & 93 (9.9\%) & 2.16 & $<0.001$ \\
\hline
\end{tabular}

${ }^{*}$ Models were adjusted for age, sex, race, pack-years, current smoking status, BMI, and $\mathrm{FEV}_{1} \%$ predicted, excluding the variable that was used to define the strata (e.g. models in obese and non-obese subjects were not adjusted for BMI). Odds ratio is for non-emphysematous compared to emphysema-predominant COPD.

non-emphysematous COPD persisted in stratified analyses of obese and non-obese subjects, current and former smokers, mild-moderate (GOLD 1-2) and severe-very severe COPD (GOLD 3-4), non-Hispanic white and African American subjects, and older and younger subjects (Table 4). Odds ratios were similar or increased in the stratified analyses using the stricter diabetes definition of self-report plus medication (data not shown). The associations with metabolic syndrome persisted in stratified analyses (Table S2).

In ECLIPSE, there were 283 non-emphysema predominant and 1211 emphysema-predominant COPD subjects (Additional file 4: Table S3). Similar to COPDGene, emphysema-predominant subjects had more severe airflow obstruction. Diabetes was reported by $10.6 \%$ of nonemphysematous and $8.2 \%$ of emphysema-predominant subjects. A logistic regression model replicated the association between diabetes and non-emphysema predominant COPD (OR 1.62, 1 -sided p-value $=0.034)$.

\section{Discussion}

In the COPDGene Study, we defined subtypes of emphysema-predominant and non-emphysematous COPD based on a distinction between high and low emphysema on chest CT scan. We found an increased prevalence of diabetes in non-emphysematous COPD subjects, which was confirmed in the ECLIPSE study. Subjects with emphysema-predominant COPD had more severe airflow obstruction, but the proportions of subjects with frequent exacerbations or exercise intolerance were similar in the two subgroups when adjusted for differences in lung function. We confirmed expected associations of asthmaCOPD overlap syndrome with non-emphysematous COPD and low BMI with emphysema-predominant COPD. The classic pink puffer - blue bloater subtypes were found in low frequencies in a modern COPD population. There was no difference in the rate of chronic bronchitis across the two subtypes, highlighting another shortcoming of this classic dichotomy. The pink puffer - blue bloater distinction is unlikely to be useful and should be abandoned.

The heterogeneous nature of COPD is increasingly recognized [2]. Previous efforts to identify subtypes of COPD have relied on statistical approaches such as cluster analysis and have identified clusters with emphysema and airway-predominant disease [40-42]. Garcia-Aymerich and colleagues found a cluster of subjects with milder COPD, obesity, diabetes, and cardiovascular disease, who had less emphysema in those subjects with CT scans [43]. These statistical approaches are promising, but they often require a large number of input variables and the output may be difficult to interpret. In our analysis, the simple distinction based on the presence or absence of emphysema yielded similar results and may be easier to apply clinically than the cluster-based methods.

Diabetes and the metabolic syndrome are frequent comorbidities in COPD patients [44-47]. COPD, diabetes, and the metabolic syndrome are all related to systemic inflammation, which may explain the co-occurrence. Studies examining whether inhaled corticosteroids increase risk of diabetes have shown conflicting results $[48,49]$. Regardless, any association between ICS and diabetes would not explain the high frequency of the other components of the metabolic syndrome in COPD.

In a subset of COPDGene subjects, Han and colleagues examined $\mathrm{CT}$ features associated with $\mathrm{COPD}$ exacerbations [33]. They found that diabetes was more frequent in subjects with airway disease, defined by airway wall measures. The current study using all COPD subjects in COPDGene extends those results, using a paucity of emphysema on CT scan as a surrogate for airway-predominant COPD. The concordant results using a simple definition of airway-predominant COPD strengthens the current findings. Inflammation in emphysema may be different from inflammation in airway disease 
[50], explaining the variable correlations between these COPD phenotypes and other diseases associated with systemic inflammation. Analyses within well-characterized cohorts of COPD patients including biomarkers, chest CT scans and comorbidities would be required to clarify these inflammatory phenotypes.

The observation that non-emphysematous COPD is associated with diabetes may have clinical implications. Current guidelines from the U.S. Preventive Services Task Force (USPTF) and other organizations recommend routine screening for hypertension and hyperlipidemia in adults [51]. However, recommendations for diabetes screening vary. The USPTF recommends diabetes screening only in adults with blood pressure greater than 135/80 mmHg [52]. The American Diabetes Association recommends screening all adults who are overweight and have one or more risk factors for diabetes, as well as all adults beginning at age 45 [53]. One might consider adding COPD, specifically nonemphysematous COPD, to the list of diabetes risk factors. With the increasing use of chest CT scans for screening and diagnosis, physicians will increasingly be able to identify COPD patients with and without emphysema. Since patients with chronic diseases may be undertreated for other medical conditions [54], our results serve as a reminder to physicians to screen for diabetes, hypertension, and lipid disorders in patients with nonemphysematous COPD. Conversely, clinicians should obtain spirometry in current and former smokers with diabetes and/or metabolic syndrome who present with respiratory symptoms.

Besides a heightened awareness of disease screening in patients with non-emphysematous COPD, our findings may potentially affect treatment. For example, the phosphodiesterase-4 inhibitor roflumilast is indicated in severe COPD patients with chronic bronchitis and frequent acute exacerbations [8]. Wouters et al. have shown that roflumilast improves glucose control in subjects with newly-diagnosed diabetes without COPD [55]. The effect of roflumilast on both COPD and diabetes outcomes in subjects with both diseases warrants further study. Since we found that chronic bronchitis was equally frequent in both imaging subtypes, non-emphysematous COPD may define a more specific subgroup that might benefit from roflumilast than does chronic bronchitis. Other antiinflammatory agents may also have beneficial effects in COPD subtypes. Our analysis has several limitations. We divided subjects into emphysema-predominant and non-emphysematous COPD, as a surrogate for airwaypredominant COPD [17]. The non-emphysematous subgroup did have large airway disease on chest CT scans. However, the major site of airflow limitation is in the small airways. Measurements of small airways $(<2 \mathrm{~mm})$ are limited due to the spatial resolution of CT scans. Additionally, the emphysema-predominant subtype may still include substantial airway disease since we did not account for CT airway measurements when defining the subtypes. In order to be clinically-relevant, we created a simple distinction on chest $\mathrm{CT}$ scans which does not require complex airway measurements. The quantitative CT emphysema categories served as a surrogate for visual reading of the presence or absence of emphysema, as would be found in a clinical radiology report. Standardized radiologist readings of chest CT scans were not available in COPDGene. However, this simplified distinction proved to be generalizable to a second study population which included COPD subjects from multiple countries.

In COPDGene, comorbidities were defined by subject self-report. Previous studies have shown subject report of diabetes to be reliable [56-58]. In addition, we confirmed our findings using a strict definition of diabetes including medication usage. However, we could not apply strict definitions of metabolic syndrome, which would require measurements of waist circumference and triglyceride, HDL, and glucose levels [59]. Using more precise definitions may strengthen the associations found using self-reported data. Additionally, we used cross-sectional data, so we cannot determine the relative timing of the onset of non-emphysematous COPD and diabetes and the metabolic syndrome. Longitudinal data would be needed to address causality. COPDGene and ECLIPSE included non-Hispanic white and non-Hispanic African American subjects; it is not known whether our findings are generalizable to other racial and ethnic groups.

\section{Conclusions}

Despite these limitations, we were able to create an imaging-based classification of emphysema-predominant and non-emphysematous COPD. The emphysemapredominant subjects had more severe COPD, based on measures of lung function, exercise capacity and symptoms. However, the non-emphysematous COPD subjects had an increased prevalence of diabetes and the metabolic syndrome, consistent with systemic inflammation. This finding may encourage clinicians to screen for diabetes and lipid abnormalities in COPD patients, specifically those without significant emphysema. With the increase in chest CT scans being performed for other indications, such as lung cancer screening, COPD patients will be more easily able to be assigned to these imaging subtypes. Conversely, patients with diabetes or metabolic syndrome who present with respiratory symptoms should undergo spirometry to evaluate for COPD. Future studies of existing and novel anti-inflammatory agents in COPD may find better results if targeted to COPD subjects without substantial emphysema. 


\section{Additional files}

\section{Additional file 1: Supplementary Methods. \\ Additional file 2: COPDGene Institutional Review Board approvals. Additional file 3: ECLIPSE Institutional Review Board approvals.}

Additional file 4: Table S1. Demographic and clinical attributes of subjects with non-emphysematous and emphysema-predominant COPD (GOLD 1-4), along with unclassified COPD subjects (5-10\% emphysema). Table S2. Stratified logistic regression analyses in COPDGene for metabolic syndrome. Table S3. ECLIPSE subjects with non-emphysematous and emphysema-predominant COPD (GOLD 2-4).

\section{Abbreviations}

BODE: Body mass index, airflow obstruction, dyspnea, and exercise capacity; COPD: Chronic obstructive pulmonary disease; COPDGene: Genetic epidemiology of COPD study; ECLIPSE: Evaluation of COPD longitudinally to identify predictive surrogate end-points; $F_{E V}$ : Forced expiratory volume in 1 second; FVC: Forced vital capacity; GOLD: Global initiative for chronic obstructive lung disease; OR: Odds ratio; SGRQ: St. George's respiratory questionnaire.

\section{Competing interests}

Dr. Hersh has received lecture fees from Novartis and has been a consultant for CSL Behring. Dr. Make reports advisory board membership for Forest, AstraZeneca, Novartis, Covidien, Breathe, Merck, Sunovion, Boehringer Ingelheim, Medlmmune, Ikaria, and Abbot. He has been a consultant for Astellas, Forest, and Boehringer Ingelheim. He has received research grants from AstraZeneca, GlaxoSmithKline, NABI, Boehringer Ingelheim, Sunovion, Forest, and Pfizer. He has received lecture fees from GlaxoSmithKline, Boehringer Ingelheim, Forest, and Pfizer. Dr. Lynch has been a consultant for Perceptive Imaging, Boehringer Ingelheim, Genentech, Gilead, and Intermune. He has received grants from Centocor and Siemens. Dr. Barr has received royalties from UpToDate. Dr. Cho has been a consultant for Merck. Dr. Han has been a consultant for GlaxoSmithKline, Boehringer Ingelheim, Novartis, Genentech, Medimmune, and Forest. She has received lecture fees from GlaxoSmithKline, Boehringer Ingelheim, Pfizer, Novartis, Grifols, and Forest. She has received royalties from UpToDate. Dr. Ramsdell has received a research grant from Boehringer Ingelheim. Dr. Rennard has received grants from AstraZeneca, Biomarck, Centocor, Mpex, Nabi, Novartis, Otsuka, Boehringer Ingelheim, and Nycomed. He has been a consultant for Able Associates, Adelphi Research, APT Pharma/Britnall, Aradigm, AstraZeneca, Boehringer Ingelheim, Chiesi, CommonHealth, Consult Complete, COPDForum, Data Monitor, Decision Resource, Defined Health, Dey, Dunn Group, Easton Associates, Equinox, Gerson, GlaxoSmithKline, Infomed, KOL Connection, M. Pankove, MedaCorp, MDRX Financial, Mpex, Novartis, Oriel Therapeutics, Otsuka, Pennside, ParmaVentures, Pharmaxis, Price Waterhouse, Propagate, Pulmatrix, Reckner Associates, recruiting Resources, Roche, Schlesinger Medical, Scimed, Sudler and Hennessey, TargeGen, Theravance, UBC, Uptake Medical, VantagePoint Management, Forest, Nycomed, Pearl and Sanyko. He has served on advisory boards for Almirall, Novartis, Nycomed, and Pfizer. He has received lecture fees from AAAAl, American College of Osteopathic Physicians, Asan Medical Center, American Thoracic Society, AstraZeneca, California Society of Allergy, Convergent Health Solutions for Reviews and Trends in COPD, COPD Foundation, Creative Educational Concepts, Dey, Duke University, France Foundation, Information TV, University of Southern California, Network for Continuing Education (CHARM), Novartis, Nycomed, Otsuka, Pfizer, Sarasota Memorial Hospital, Spanish Thoracic Society, University of Washington, University of Alabama Birmingham, University of Pittsburgh, University of British Columbia, University of California Davis, and Sioux Falls VA. Dr. Sciurba has participated in consulting for GSK, AstraZeneca and Pfizer and has received research grant funding from the NIH, GSK, BI, Pfizer, Forest and Actelion. Dr. Steiner reports royalties from Elsevier Publishing and consultancy for Johnson and Johnson. Dr. van Beek is a board member of Quantitative Clinical Trials Imaging Services, Inc. He has been a consultant for Siemens Medical Systems, Synta Pharmaceuticals, and Skolkovo Foundation. He has received speaking fees from Vital Images Inc and Toshiba Medical Systems. Dr. Silverman has been a consultant for GlaxoSmithKline, AstraZeneca, and Merck. He has received research grants from GlaxoSmithKline. He has received speaking fees from GlaxoSmithKline and AstraZeneca. Dr. Calverley reports advisory board membership for AstraZeneca, Merck, Boehringer Ingelheim, GSK and Takeda. He has been a consultant for Boehringer Ingelheim, GSK and Takeda. He has received research grants from GlaxoSmithKline, Boehringer Ingelheim, and Takeda. Dr. Coxson has received consulting fees and research grants from GlaxoSmithKline and a research grant from Spiration. Dr. Tal-Singer is an employee and shareholder of GlaxoSmithKline. Drs. Bowler, Castaldi, DeMeo, Foreman, Hokanson, Lutz, Regan, Schroeder and Crapo and Mr. Harshfield report no disclosures.

\section{Authors' contributions}

Concept and design: $\mathrm{CPH}, \mathrm{BJM}, \mathrm{EKS}$ and JDC. Acquisition of data: $\mathrm{CPH}, \mathrm{BJM}$ DAL, RGB, RPB, HOC, PMAC, DLDM, MGF, MKH, JWR, EAR, SIR, JDS, FCS, RMS, EKS and JDC. Analysis and interpretation of data: $\mathrm{CPH}, \mathrm{BJM}, \mathrm{DAL}, \mathrm{PJC}, \mathrm{MHC}$, HOC, BJH, JEH, SL, SIR, EJRB, JDS, EKS and JDC. Drafting of manuscript: CPH. Critical revision of manuscript: $C P H, B J M, D A L, R G B, R P B, P M A C, P J C, M H C$, HOC, DLDM, MGF, MKH, BJH, JEH, SL, JWR, EAR, SIR, JDS, FCS, RMS, RTS, EJRB, EKS, JDC. Funding: CPH, EKS, JDC. All authors read and approved the final manuscript.

\section{Funding}

Supported by U.S. National Institutes of Health grants R01HL094635 (CPH), R01NR013377 (CPH), R01HL089856 (EKS), R01HL089897 (JDC), P01HL105339 (EKS). COPDGene is also supported by the COPD Foundation through contributions made to an Industry Advisory Board comprised of AstraZeneca, Pfizer, Novartis, Boehringer-Ingelheim, Siemens, Sunovion, and GlaxoSmithKline. ECLIPSE is supported by GlaxoSmithKline. The sponsors had no role in study design; collection, analysis, and interpretation of the data; preparation of the manuscript; and decision to submit the manuscript for publication.

COPDGene ${ }^{\oplus}$ Investigators - Core Units Administrative Core: James Crapo, MD (PI), Edwin Silverman, MD, PhD (PI), Barry Make, MD, Elizabeth Regan, MD, Rochelle Lantz, Lori Stepp, Sandra Melanson

Genetic Analysis Core: Terri Beaty, PhD, Nan Laird, PhD, Christoph Lange, PhD, Michael Cho, MD, Stephanie Santorico, PhD, John Hokanson, MPH, PhD, Dawn DeMeo, MD, MPH, Nadia Hansel, MD, MPH, Craig Hersh, MD, MPH, Peter Castaldi, MD, MSc, Merry-Lynn McDonald, PhD, Jin Zhou, PhD, Manuel Mattheisen, MD, Emily Wan, MD, Megan Hardin, MD, Jacqueline Hetmanski, MS, Margaret Parker, MS, Tanda Murray, MS

Imaging Core: David Lynch, MB, Joyce Schroeder, MD, John Newell, Jr., MD, John Reilly, MD, Harvey Coxson, PhD, Philip Judy, PhD, Eric Hoffman, PhD, George Washko, MD, Raul San Jose Estepar, PhD, James Ross, MSc, Mustafa Al Qaisi, MD, Jordan Zach, Alex Kluiber, Jered Sieren, Tanya Mann, Deanna Richert, Alexander McKenzie, Jaleh Akhavan, Douglas Stinson PFT QA Core, National Jewish Health: Robert Jensen, PhD Biological Repository, Johns Hopkins University, Baltimore, MD: Homayoon Farzadegan, PhD, Stacey Meyerer, Shivam Chandan, Samantha Bragan Data Coordinating Center and Biostatistics, National Jewish Health, Denver, CO: Douglas Everett, PhD, Andre Williams, PhD, Carla Wilson, MS, Anna Forssen, MS, Amber Powell, Joe Piccoli

Epidemiology Core, University of Colorado School of Public Health, Denver, CO: John Hokanson, MPH, PhD, Marci Sontag, PhD, Jennifer Black-Shinn, MPH, Gregory Kinney, MPH, PhDc, Sharon Lutz, MPH, PhD COPDGene ${ }^{\oplus}$ Investigators: Clinical Centers Ann Arbor VA: Jeffrey Curtis, MD, Ella Kazerooni, MD Baylor College of Medicine, Houston, TX: Nicola Hanania, MD, MS, Philip Alapat, MD, Venkata Bandi, MD, Kalpalatha Guntupalli, MD, Elizabeth Guy, MD, Antara Mallampalli, MD, Charles Trinh, MD, Mustafa Atik, MD, Hasan Al-Azzawi, MD, Marc Willis, DO, Susan Pinero, MD, Linda Fahr, MD, Arun Nachiappan, MD, Collin Bray, MD, L. Alexander Frigini, MD, Carlos Farinas, MD, David Katz, MD, Jose Freytes, MD, Anne Marie Marciel, MD Brigham and Women's Hospital, Boston, MA: Dawn DeMeo, MD, MPH, Craig Hersh, MD, MPH, George Washko, MD, Francine Jacobson, MD, MPH, Hiroto Hatabu, MD, PhD, Peter Clarke, MD, Ritu Gill, MD, Andetta Hunsaker, MD, Beatrice Trotman-Dickenson, MBBS, Rachna Madan, MD Columbia University, New York, NY: R. Graham Barr, MD, DrPH, Byron Thomashow, MD, John Austin, MD, Belinda D'Souza, MD Duke University Medical Center, Durham, NC: Neil Maclntyre, Jr., MD, Lacey Washington, MD, H Page McAdams, MD 
Reliant Medical Group, Worcester, MA: Richard Rosiello, MD, Timothy Bresnahan, MD, Joseph Bradley, MD, Sharon Kuong, MD, Steven Meller, MD, Suzanne Roland, MD

Health Partners Research Foundation, Minneapolis, MN: Charlene McEvoy, MD, MPH, Joseph Tashjian, MD

Johns Hopkins University, Baltimore, MD: Robert Wise, MD, Nadia Hansel, MD, MPH, Robert Brown, MD, Gregory Diette, MD, Karen Horton, MD Los Angeles Biomedical Research Institute at Harbor UCLA Medical Center, Torrance, CA: Richard Casaburi, MD, PhD, Janos Porszasz, MD, PhD, Hans Fischer, MD, Matt Budoff, MD

Michael E. DeBakey VAMC, Houston, TX: Amir Sharafkhaneh, MD, Charles Trinh, MD, Hirani Kamal, MD, Roham Darvishi, MD, Marc Willis, DO, Susan Pinero, MD, Linda Fahr, MD, Arun Nachiappan, MD, Collin Bray, MD, L. Alexander Frigini, MD, Carlos Farinas, MD, David Katz, MD, Jose Freytes, MD, Anne Marie Marciel, MD

Minneapolis VA: Dennis Niewoehner, MD, Quentin Anderson, MD, Kathryn Rice, MD, Audrey Caine, MD

Morehouse School of Medicine, Atlanta, GA: Marilyn Foreman, MD, MS, Gloria Westney, MD, MS, Eugene Berkowitz, MD, PhD

National Jewish Health, Denver, CO: Russell Bowler, MD, PhD, David Lynch, $M B$, Joyce Schroeder, MD, Valerie Hale, MD, John Armstrong, II, MD, Debra Dyer, MD, Jonathan Chung, MD, Christian Cox, MD

Temple University, Philadelphia, PA: Gerard Criner, MD, Victor Kim, MD, Nathaniel Marchetti, DO, Aditi Satti, MD, A. James Mamary, MD, Robert Steiner, MD, Chandra Dass, MD, Libby Cone, MD

University of Alabama, Birmingham, AL: William Bailey, MD, Mark Dransfield, MD, Michael Wells, MD, Surya Bhatt, MD, Hrudaya Nath, MD, Satinder Singh, MD University of California, San Diego, CA: Joe Ramsdell, MD, Paul Friedman, MD University of lowa, lowa City, IA: Alejandro Cornellas, MD, John Newell, Jr., MD, Edwin JR van Beek, MD, PhD

University of Michigan, Ann Arbor, MI: Fernando Martinez, MD, MeiLan Han, $\mathrm{MD}$, Ella Kazerooni, MD

University of Minnesota, Minneapolis, MN: Christine Wendt, MD, Tadashi Allen, MD University of Pittsburgh, Pittsburgh, PA: Frank Sciurba, MD, Joel Weissfeld, MD, $\mathrm{MPH}$, Carl Fuhrman, MD, Jessica Bon, MD, Danielle Hooper, MD

University of Texas Health Science Center at San Antonio, San Antonio, TX: Antonio Anzueto, MD, Sandra Adams, MD, Carlos Orozco, MD, Mario Ruiz, MD, Amy Mumbower, MD, Ariel Kruger, MD, Carlos Restrepo, MD, Michael Lane, MD Principal investigators and centers participating in ECLIPSE include: Bulgaria: Y. Ivanov, Pleven; K. Kostov, Sofia. Canada: J. Bourbeau, Montreal QC; M. Fitzgerald, Vancouver BC; P. Hernández, Halifax NS; K. Killian, Hamilton ON; R. Levy, Vancouver BC; F. Maltais, Montreal QC; D. O'Donnell, Kingston ON. Czech Republic: J. Krepelka, Prague. Denmark: J. Vestbo, Hvidovre. The Netherlands: E. Wouters, Horn-Maastricht. New Zealand: D. Quinn, Wellington. Norway: P. Bakke, Bergen. Slovenia: M. Kosnik, Golnik. Spain: A. Agusti, J. Sauleda, Palma de Mallorca. Ukraine: Y. Feschenko, V. Gavrisyuk, L. Yashina, Kiev N. Monogarova, Donetsk. United Kingdom: P. Calverley, Liverpool; D. Lomas, Cambridge; W. MacNee, Edinburgh; D. Singh, Manchester; J. Wedzicha, London. United States: A. Anzueto, San Antonio, TX; S. Braman, Providence. Rl; R. Casaburi, Torrance CA; B. Celli, Boston, MA; G. Giessel, Richmond, VA; M. Gotfried, Phoenix, AZ; G. Greenwald, Rancho Mirage, CA; N. Hanania, Houston, TX; D. Mahler, Lebanon, NH; B. Make, Denver, CO; S. Rennard, Omaha, NE; C. Rochester, New Haven, CT; P. Scanlon, Rochester, MN; D. Schuller, Omaha, NE; F. Sciurba, Pittsburgh, PA; A. Sharafkhaneh, Houston, TX; T. Siler, St Charles, MO; E. Silverman, Boston, MA; A. Wanner, Miami, FL; R. Wise, Baltimore, MD; R. ZuWallack, Hartford, CT.

Steering Committee: H. Coxson (Canada), C. Crim (GlaxoSmithKline, USA), L. Edwards (GlaxoSmithKline, USA), D. Lomas (UK), W. MacNee (UK), E. Silverman (USA), R. Tal Singer (Co-chair, GlaxoSmithKline, USA), J. Vestbo (Co-chair, Denmark), J. Yates (GlaxoSmithKline, USA).

Scientific Committee: A. Agusti (Spain), P. Calverley (UK), B. Celli (USA), C. Crim (GlaxoSmithKline, USA), B. Miller (GlaxoSmithKline, USA), W. MacNee (Chair, UK), S. Rennard (USA), R. Tal-Singer (GlaxoSmithKline, USA), E. Wouters (The Netherlands), J. Yates (GlaxoSmithKline, USA).

\section{Author details}

${ }^{1}$ Channing Division of Network Medicine, Boston, MA, USA. ${ }^{2}$ Division of Pulmonary and Critical Care Medicine, Brigham and Women's Hospital, Boston, MA, USA. ${ }^{3}$ Division of Pulmonary and Critical Care Medicine, National Jewish Health, Denver, CO, USA. ${ }^{4}$ Department of Radiology, National Jewish Health, Denver, CO, USA. ${ }^{5}$ Department of Medicine, Columbia University,
New York, NY, USA. 'Division of Infection and Immunity Clinical Sciences Centre, University Hospital Aintree, Liverpool, UK. ${ }^{7}$ Department of Radiology, University of British Columbia, Vancouver, Canada. ${ }^{8}$ Division of Pulmonary and Critical Care Medicine, Morehouse School of Medicine, Atlanta, GA, USA ${ }^{9}$ Division of Pulmonary and Critical Care Medicine, University of Michigan Health System, Ann Arbor, MI, USA. ${ }^{10}$ Department of Epidemiology, Colorado School of Public Health, Aurora, CO, USA. ${ }^{11}$ Department of Biostatistics, Colorado School of Public Health, Aurora, CO, USA. ${ }^{12}$ Division of Pulmonary and Critical Care Medicine, University of California, San Diego, CA, USA. ${ }^{13}$ Division of Pulmonary, Critical Care, Sleep and Allergy, University of Nebraska Medical Center, Omaha, NE, USA. ${ }^{14}$ Division of Pulmonary, Allergy, and Critical Care Medicine, University of Pittsburgh, Pittsburgh, PA, USA.

${ }^{15}$ Department of Radiology, Temple University, Philadelphia, PA, USA.

${ }^{16}$ GlaxoSmithKline R\&D, King of Prussia, PA, USA. ${ }^{17}$ Department of Radiology, University of Edinburgh, Edinburgh, Scotland.

Received: 6 May 2014 Accepted: 9 October 2014

Published: 24 October 2014

\section{References}

1. Vestbo J, Hurd SS, Agusti AG, Jones PW, Vogelmeier C, Anzueto A, Barnes PJ, Fabbri LM, Martinez FJ, Nishimura M, Stockley RA, Sin DD, Rodriguez-Roisin R: Global strategy for the diagnosis, management, and prevention of chronic obstructive pulmonary disease: GOLD executive summary. Am J Respir Crit Care Med 2012, 187(4):347-365.

2. Han MK, Agusti A, Calverley PM, Celli BR, Criner G, Curtis JL, Fabbri LM, Goldin JG, Jones PW, Macnee W, Make BJ, Rabe KF, Rennard SI, Sciurba FC, Silverman EK, Vestbo J, Washko GR, Wouters EF, Martinez FJ: Chronic obstructive pulmonary disease phenotypes: the future of COPD. Am J Respir Crit Care Med 2010, 182(5):598-604.

3. Nocturnal Oxygen Therapy Trial Group: Continuous or nocturnal oxygen therapy in hypoxemic chronic obstructive lung disease: a clinical trial. Ann Intern Med 1980, 93(3):391-398.

4. Medical Research Council Working Party: Long term domiciliary oxygen therapy in chronic hypoxic cor pulmonale complicating chronic bronchitis and emphysema. Lancet 1981, 1(8222):681-686.

5. Fishman A, Martinez F, Naunheim K, Piantadosi S, Wise R, Ries A, Weinmann G, Wood DE: A randomized trial comparing lung-volumereduction surgery with medical therapy for severe emphysema. $N$ Engl J Med 2003, 348(21):2059-2073.

6. Albert RK, Connett J, Bailey WC, Casaburi R, Cooper JA Jr, Criner GJ, Curtis JL, Dransfield MT, Han MK, Lazarus SC, Make B, Marchetti N, Martinez FJ, Madinger NE, McEvoy C, Niewoehner DE, Porsasz J, Price CS, Reilly J, Scanlon PD, Sciurba FC, Scharf SM, Washko GR, Woodruff PG, Anthonisen NR, COPD Clinical Research Network: Azithromycin for prevention of exacerbations of COPD. N Engl J Med 2011, 365(8):689-698.

7. Yang IA, Fong KM, Sim EH, Black PN, Lasserson TJ: Inhaled corticosteroids for stable chronic obstructive pulmonary disease. Cochrane Database Syst Rev 2007, 2:CD002991.

8. Calverley PM, Rabe KF, Goehring UM, Kristiansen S, Fabbri LM, Martinez FJ: Roflumilast in symptomatic chronic obstructive pulmonary disease: two randomised clinical trials. Lancet 2009, 374(9691):685-694.

9. Dornhorst AC: Respiratory insufficiency. Lancet 1955, 268(6876):1185-1187.

10. Qaseem A, Wilt TJ, Weinberger SE, Hanania NA, Criner G, van der Molen T, Marciniuk DD, Denberg T, Schunemann H, Wedzicha W, MacDonald R, Shekelle P, American College of Physicians, American College of Chest Physicians, American Thoracic Society, European Respiratory Society: Diagnosis and management of stable chronic obstructive pulmonary disease: a clinical practice guideline update from the American College of Physicians, American College of Chest Physicians, American Thoracic Society, and European Respiratory Society. Ann Intern Med 2011, 155(3):179-191.

11. Weinberger SE, Cockrill BA, Mandel J: Chronic obstructive pulmonary disease. In Principles of Pulmonary Medicine. 5th edition. Philadelphia: Saunders Elsevier; 2008:90-109.

12. Niewoehner DE: Chronic obstructive pulmonary disease. In Goldman's Cecil Medicine. 24th edition. Edited by Goldman L, Schafer Al. Philadelphia: Elsevier Saunders; 2012:537-544.

13. Boschetto P, Miniati M, Miotto D, Braccioni F, De Rosa E, Bononi I, Papi A, Saetta M, Fabbri LM, Mapp CE: Predominant emphysema phenotype in chronic obstructive pulmonary. Eur Respir J 2003, 21(3):450-454. 
14. Makita H, Nasuhara Y, Nagai $K$, Ito Y, Hasegawa M, Betsuyaku T, Onodera Y, Hizawa N, Nishimura M: Characterisation of phenotypes based on severity of emphysema in chronic obstructive pulmonary disease. Thorax 2007, 62(11):932-937.

15. Kitaguchi Y, Fujimoto K, Kubo K, Honda T: Characteristics of COPD phenotypes classified according to the findings of HRCT. Respir Med 2006, 100(10):1742-1752

16. Hersh CP, Hansel NN, Barnes KC, Lomas DA, Pillai SG, Coxson HO Mathias RA, Rafaels NM, Wise RA, Connett JE, Klanderman BJ, Jacobson FL, Gill R, Litonjua AA, Sparrow D, Reilly JJ, Silverman EK, ICGN Investigators: Transforming growth factor-beta receptor-3 is associated with pulmonary emphysema. Am J Respir Cell Mol Biol 2009, 41(3):324-331.

17. Hersh CP, Jacobson FL, Gill R, Silverman EK: Computed tomography phenotypes in severe, early-onset chronic obstructive pulmonary disease. COPD 2007, 4(4):331-337.

18. Muller NL, Staples CA, Miller RR, Abboud RT: "Density mask". An objective method to quantitate emphysema using computed tomography. Chest 1988, 94(4):782-787.

19. Nakano $Y$, Wong JC, de Jong PA, Buzatu L, Nagao T, Coxson HO, Elliott WM, Hogg JC, Pare PD: The prediction of small airway dimensions using computed tomography. Am J Respir Crit Care Med 2005, 171(2):142-146.

20. Aberle DR, Adams AM, Berg CD, Black WC, Clapp JD, Fagerstrom RM, Gareen IF, Gatsonis C, Marcus PM, Sicks JD: Reduced lung-cancer mortality with low-dose computed tomographic screening. N Engl J Med 2011, 365(5):395-409.

21. Mets OM, Buckens CF, Zanen P, Isgum I, van Ginneken B, Prokop M, Gietema HA, Lammers JW, Vliegenthart R, Oudkerk M, van Klaveren RJ, de Koning HJ, Mali WP, de Jong PA: Identification of chronic obstructive pulmonary disease in lung cancer screening computed tomographic scans. JAMA 2011, 306(16):1775-1781.

22. Regan EA, Hokanson JE, Murphy JR, Make B, Lynch DA, Beaty TH, Curran-Everett D, Silverman EK, Crapo JD: Genetic epidemiology of COPD (COPDGene) study design. COPD 2010, 7(1):32-43

23. Vestbo J, Anderson W, Coxson HO, Crim C, Dawber F, Edwards L, Hagan G, Knobil K, Lomas DA, MacNee W, Silverman EK, Tal-Singer R, ECLIPSE Investigators: Evaluation of COPD Longitudinally to Identify Predictive Surrogate End-points (ECLIPSE). Eur Respir J 2008, 31(4):869-873.

24. Jones PW, Quirk FH, Baveystock CM, Littlejohns P: A self-complete measure of health status for chronic airflow limitation. The St George's Respiratory Questionnaire. Am Rev Respir Dis 1992, 145(6):1321-1327.

25. Estepar RS, Washko GG, Silverman EK, Reilly JJ, Kikinis R, Westin CF: Accurate airway wall estimation using phase congruency. Med Image Comput Comput Assist Interv Int Conf Med Image Comput Comput Assist Interv 2006, 9(Pt 2):125-134

26. Hersh CP, Washko GR, Jacobson FL, Gill R, Estepar RS, Reilly JJ, Silverman EK: Interobserver variability in the determination of upper lobe-predominant emphysema. Chest 2007, 131(2):424-431.

27. Gevenois PA, De Vuyst P, de Maertelaer V, Zanen J, Jacobovitz D, Cosio MG, Yernault JC: Comparison of computed density and microscopic morphometry in pulmonary emphysema. Am J Respir Crit Care Med 1996, 154(1):187-192.

28. Zach JA, Newell JD Jr, Schroeder J, Murphy JR, Curran-Everett D, Hoffman EA, Westgate PM, Han MK, Silverman EK, Crapo JD, Lynch DA, COPDGene Investigators: Quantitative computed tomography of the lungs and airways in healthy nonsmoking adults. Invest Radiol 2012, 47(10):596-602.

29. Hardin M, Silverman EK, Barr RG, Hansel NN, Schroeder JD, Make BJ, Crapo JD, Hersh CP, COPDGene Investigators: The clinical features of the overlap between COPD and asthma. Respir Res 2011, 12(1):127.

30. Kim DK, Jacobson FL, Washko GR, Casaburi R, Make BJ, Crapo JD, Silverman EK, Hersh CP: Clinical and radiographic correlates of hypoxemia and oxygen therapy in the COPDGene study. Respir Med 2011, 105(8):1211-1221.

31. Kim V, Han MK, Vance GB, Make BJ, Newell JD, Hokanson JE, Hersh CP, Stinson D, Silverman EK, Criner GJ: The chronic bronchitic phenotype of COPD: an analysis of the COPDGene Study. Chest 2011, 140(3):626-633.

32. Rambod M, Porszasz J, Make BJ, Crapo JD, Casaburi R: Six-minute walk distance predictors, including CT scan measures, in the COPDGene cohort. Chest 2012, 141(4):867-875.

33. Han MK, Kazerooni EA, Lynch DA, Liu LX, Murray S, Curtis JL, Criner GJ, Kim V, Bowler RP, Hanania NA, Anzueto AR, Make BJ, Hokanson JE, Crapo JD, Silverman EK, Martinez FJ, Washko GR, COPDGene Investigators:
Chronic obstructive pulmonary disease exacerbations in the COPDGene study: associated radiologic phenotypes. Radiology 2011, 261(1):274-282.

34. Foreman MG, Zhang L, Murphy J, Hansel NN, Make B, Hokanson JE, Washko G, Regan EA, Crapo JD, Silverman EK, DeMeo DL, COPDGene Investigators: Early-onset chronic obstructive pulmonary disease is associated with female sex, maternal factors, and African American race in the COPDGene Study. Am J Respir Crit Care Med 2011, 184(4):414-420.

35. Swift I, Satti A, Kim V, Make BJ, Newell J, Steiner RM, Wilson C, Murphy JR, Silverman EK, Criner GJ: Demographic, physiologic and radiographic characteristics of COPD patients taking chronic systemic corticosteroids. COPD 2012, 9(1):29-35.

36. Black-Shinn JL, Kinney GL, Wise AL, Regan EA, Make B, Krantz MJ, Barr RG, Murphy JR, Lynch D, Silverman EK, Crapo JD, Hokanson JE, COPDGene Investigators: Cardiovascular disease is associated with COPD severity and reduced functional status and quality of life. COPD 2014, 11(5):546-551.

37. Kinney GL, Black-Shinn JL, Wan ES, Make B, Regan E, Lutz S, Soler X, Silverman EK, Crapo J, Hokanson JE: Pulmonary function reduction in diabetes with and without chronic obstructive pulmonary disease. Diabetes Care 2014, 37(2):389-395.

38. Celli BR, Cote CG, Marin JM, Casanova C, Montes de Oca M, Mendez RA, Pinto Plata V, Cabral HJ: The body-mass index, airflow obstruction, dyspnea, and exercise capacity index in chronic obstructive pulmonary disease. N Engl J Med 2004, 350(10):1005-1012.

39. Pellegrino R, Viegi G, Brusasco V, Crapo RO, Burgos F, Casaburi R, Coates A, van der Grinten CP, Gustafsson P, Hankinson J, Jensen R, Johnson DC, MacIntyre N, McKay R, Miller MR, Navajas D, Pedersen OF, Wanger J: Interpretative strategies for lung function tests. Eur Respir J 2005, 26(5):948-968.

40. Pistolesi M, Camiciottoli G, Paoletti M, Marmai C, Lavorini F, Meoni E, Marchesi C, Giuntini C: Identification of a predominant COPD phenotype in clinical practice. Respir Med 2008, 102(3):367-376.

41. Cho MH, Washko GR, Hoffmann TJ, Criner GJ, Hoffman EA, Martinez FJ, Laird N, Reilly JJ, Silverman EK: Cluster analysis in severe emphysema subjects using phenotype and genotype data: an exploratory investigation. Respir Res 2010, 11:30.

42. Castaldi PJ, Dy J, Ross J, Chang Y, Washko GR, Curran-Everett D, Williams A, Lynch DA, Make BJ, Crapo JD, Bowler RP, Regan EA, Hokanson JE, Kinney GL, Han MK, Soler X, Ramsdell JW, Barr RG, Foreman M, van Beek E, Casaburi R, Criner GJ, Lutz SM, Rennard SI, Santorico S, Sciurba FC, DeMeo DL, Hersh CP Silverman EK, Cho MH: Cluster analysis in the COPDGene study identifies subtypes of smokers with distinct patterns of airway disease and emphysema. Thorax 2014, 69(5):415-422.

43. Garcia-Aymerich J, Gomez FP, Benet M, Farrero E, Basagana X, Gayete A, Pare C, Freixa X, Ferrer J, Ferrer A, Roca J, Galdiz JB, Sauleda J, Monso E, Gea J, Barbera JA, Agusti A, Anto JM, PAC-COPD Study Group: Identification and prospective validation of clinically relevant chronic obstructive pulmonary disease (COPD) subtypes. Thorax 2011, 66(5):430-437.

44. Agusti A, Calverley PM, Celli B, Coxson HO, Edwards LD, Lomas DA, MacNee W Miller BE, Rennard S, Silverman EK, Tal-Singer R, Wouters E, Yates JC, Vestbo J, Evaluation of COPD Longitudinally to Identify Predictive Surrogate Endpoints (ECLIPSE) investigators: Characterisation of COPD heterogeneity in the ECLIPSE cohort. Respir Res 2010, 11:122.

45. Martinez $\mathrm{CH}$, Han MK: Contribution of the environment and comorbidities to chronic obstructive pulmonary disease phenotypes. Med Clin North Am 2012, 96(4):713-727.

46. Divo M, Cote C, de Torres JP, Casanova C, Marin JM, Pinto-Plata V, Zulueta J, Cabrera C, Zagaceta J, Hunninghake G, Celli B, BODE Collaborative Group: Comorbidities and risk of mortality in patients with chronic obstructive pulmonary disease. Am J Respir Crit Care Med 2012, 186(2):155-161.

47. Clini E, Crisafulli E, Radaeli A, Malerba M: COPD and the metabolic syndrome: an intriguing association. Intern Emerg Med 2013, 8(4):283-289.

48. Suissa S, Kezouh A, Ernst P: Inhaled corticosteroids and the risks of diabetes onset and progression. Am J Med 2010, 123(11):1001-1006.

49. O'Byrne PM, Rennard S, Gerstein H, Radner F, Peterson S, Lindberg B, Carlsson LG, Sin DD: Risk of new onset diabetes mellitus in patients with asthma or COPD taking inhaled corticosteroids. Respir Med 2012, 106(11):1487-1493.

50. Bon JM, Leader JK, Weissfeld JL, Coxson HO, Zheng B, Branch RA, Kondragunta V, Lee JS, Zhang Y, Choi AM, Lokshin AE, Kaminski N, Gur D, Sciurba FC: The influence of radiographic phenotype and smoking status 
on peripheral blood biomarker patterns in chronic obstructive pulmonary disease. PLoS One 2009, 4(8):e6865.

51. U.S. Preventive Services Task Force: Screening for high blood pressure: U.S. Preventive Services Task Force reaffirmation recommendation statement. Ann Intern Med 2007, 147(11):783-786.

52. U.S. Preventive Services Task Force: Screening for type 2 diabetes mellitus in adults: U.S. Preventive Services Task Force recommendation statement. Ann Intern Med 2008, 148(11):846-854.

53. American Diabetes Association: Standards of medical care in diabetes-2012. Diabetes Care 2012, 35(Suppl 1):S11-S63.

54. Redelmeier DA, Tan SH, Booth GL: The treatment of unrelated disorders in patients with chronic medical diseases. $N$ Engl J Med 1998, 338(21):1516-1520.

55. Wouters EF, Bredenbroker D, Teichmann P, Brose M, Rabe KF, Fabbri LM, Goke B: Effect of the phosphodiesterase 4 inhibitor roflumilast on glucose metabolism in patients with treatment-naive, newly diagnosed type 2 diabetes mellitus. J Clin Endocrinol Metab 2012, 97(9):E1720-E1725.

56. Midthjell K, Holmen J, Bjorndal A, Lund-Larsen G: Is questionnaire information valid in the study of a chronic disease such as diabetes? The Nord-Trondelag diabetes study. J Epidemiol Community Health 1992, 46(5):537-542.

57. Beckett $M$, Weinstein M, Goldman N, Yu-Hsuan L: Do health interview surveys yield reliable data on chronic illness among older respondents? Am J Epidemiol 2000, 151(3):315-323.

58. Oksanen T, Kivimaki M, Pentti J, Virtanen M, Klaukka T, Vahtera J: Self-report as an indicator of incident disease. Ann Epidemiol 2010, 20(7):547-554.

59. Grundy SM, Cleeman JI, Daniels SR, Donato KA, Eckel RH, Franklin BA, Gordon DJ, Krauss RM, Savage PJ, Smith SC Jr, Spertus JA, Costa F, American Heart Association, National Heart Lung and Blood Institute: Diagnosis and management of the metabolic syndrome: an American Heart Association/National Heart, Lung, and Blood Institute Scientific Statement. Circulation 2005, 112(17):2735-2752.

doi:10.1186/1471-2466-14-164

Cite this article as: Hersh et al:: Non-emphysematous chronic obstructive pulmonary disease is associated with diabetes mellitus. BMC Pulmonary Medicine 2014 14:164.

\section{Submit your next manuscript to BioMed Central and take full advantage of:}

- Convenient online submission

- Thorough peer review

- No space constraints or color figure charges

- Immediate publication on acceptance

- Inclusion in PubMed, CAS, Scopus and Google Scholar

- Research which is freely available for redistribution 